Article

\title{
The Genes of Tulou: A Study on the Preservation and Sustainable Development of Tulou
}

\author{
Shao-Sen Wang *, Su-Yu Li and Shi-Jie Liao \\ School of Architecture and Civil Engineering, Xiamen University, Xiamen 361005, China; \\ E-Mails: njfishli@qq.com (S.-Y.L.); 309725690@qq.com (S.-J.L.) \\ * Author to whom correspondence should be addressed; E-Mail: w3m@vip.sina.com.
}

Received: 19 October 2012; in revised form: 28 November 2012 / Accepted: 11 December 2012 / Published: 18 December 2012

\begin{abstract}
This paper analyzes the formation of Tulou villages and the characteristics of Tulou buildings. The genes of the Tulou are examined within the unique physical forms and the significant social culture background. The paper is concerned with how to apply the valuable genes in the preservation and sustainable development of Tulou with a special case analysis.
\end{abstract}

Keywords: Tulou; genes; preservation; sustainable development; Hakka culture; earthen buildings; round houses; sustainability

\section{Introduction}

Tulou is a unique type of rural dwelling in China which carries with it its social background, history, and local culture [1-4]. The Tulou provides an important architectural gene pool, in which many valuable genes can be abstracted for contemporary architectural design [5,6]. The gene of Tulou refers to a combination of factors which affected the formation and development of Tulou, as well as its morphological characteristics. It includes both recessive genes of social culture, and dominant genes of physical characteristics. There are two groups of genes in Tulou. One group includes genes of social culture, which note the history of society and culture. Each Tulou village reflects the order of consanguinity habitation, environmental concern, respect for nature, a concept of fully using local resources, etc (Figure 1). The other group is comprised of genes of physical morphology, such as varied building styles, a self-contained system, use of natural colors, cohesive space, feasible 
techniques, among others. All these genes deserve in-depth understanding for suitable preservation and sustainable development of Tulou.

Figure 1. The relationship between Tulou and nature is that it expresses the Chinese ancient philosophy of harmony between man and nature.

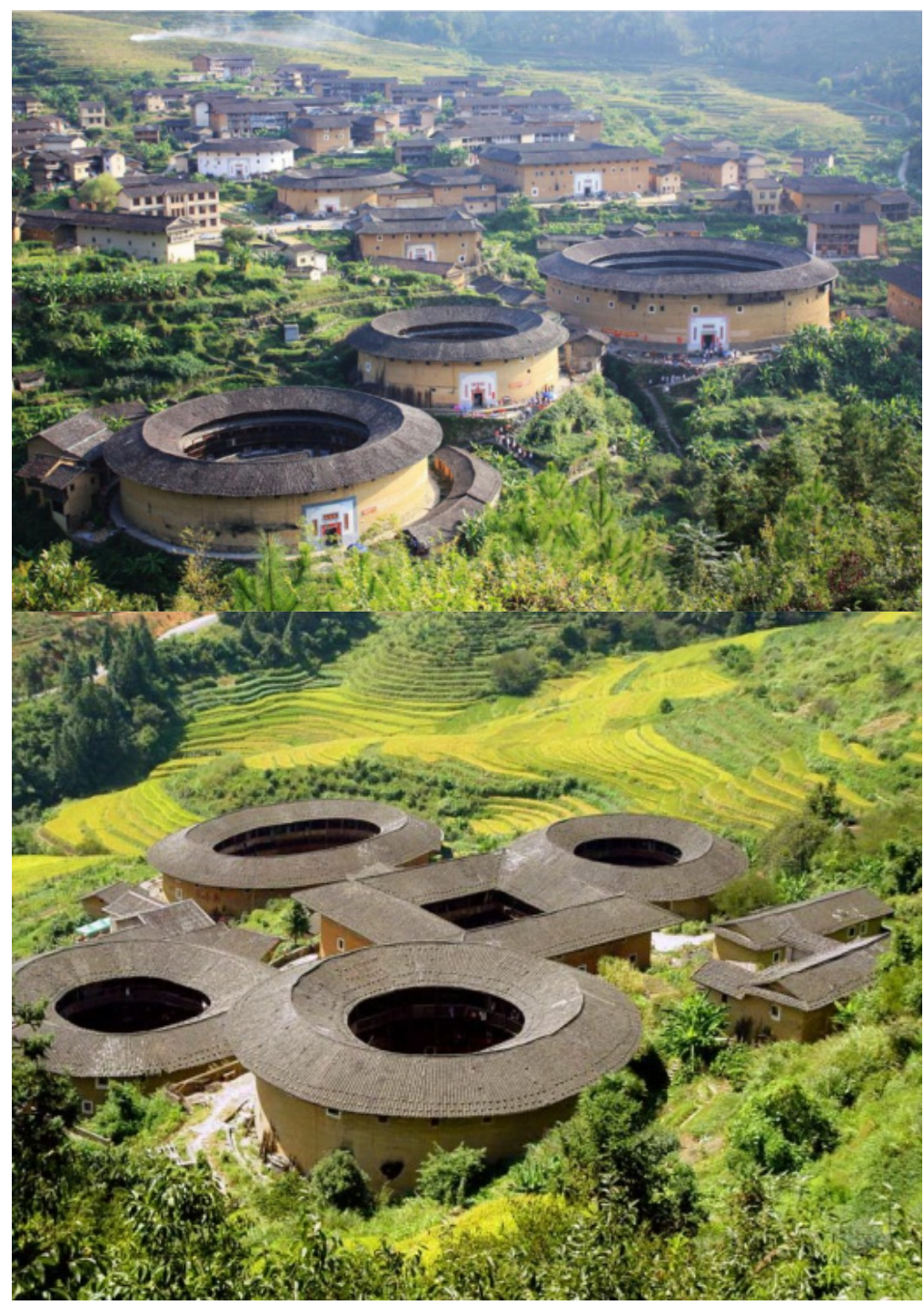

photo: xmuw3m 2009-05; Tianluokeng village, Nanjing, Fujian, China.

\section{The Genes of Social Culture}

Since the beginning, Tulou has been recording the society, the history and the culture of the time [3]. It is a good interpretation of the relationship between the Chinese people and nature. It also embodies the typical oriental philosophy.

\subsection{Record of Society, History and Culture}

Tulou evolves with the development of society. It is evidence of the migration from the central plains to refuge in southern area of China (Figure 2). As the footprint of the history, Tulou is of great significance to anthro-sociological study. From the aspect of sociology, a Tulou is usually occupied by 
one large family clan of several generations. The family clan unites together to face risk and defend each others, the Tulou house in which people are living together is the effective stronghold space. It exhibits its unique characteristic as a model of the community housing of equals. Moreover, one vertical set of Tulou section from ground floor to "penthouse" floor serves as a living unite. Each family does not only maintain its privacy, but also enjoys social communication with others. Nowadays, the community dependence is weakening while emphasis on private property is strengthening. Both communal living and privacy should be fully satisfied. The many inscribed tablets, the couplets on pillars and in the ancestral hall, are the location of cultural life in Tulou. In the active scenes of life in the Tulou, one finds the concept of "Fengshui", a farming-learning culture, as well as the Confucian ideology of order. The overall harmony is the essence of traditional culture and it should be actively promoted (Figure 3 ).

Figure 2. The route of the Hakka people from the central plains to southern area.

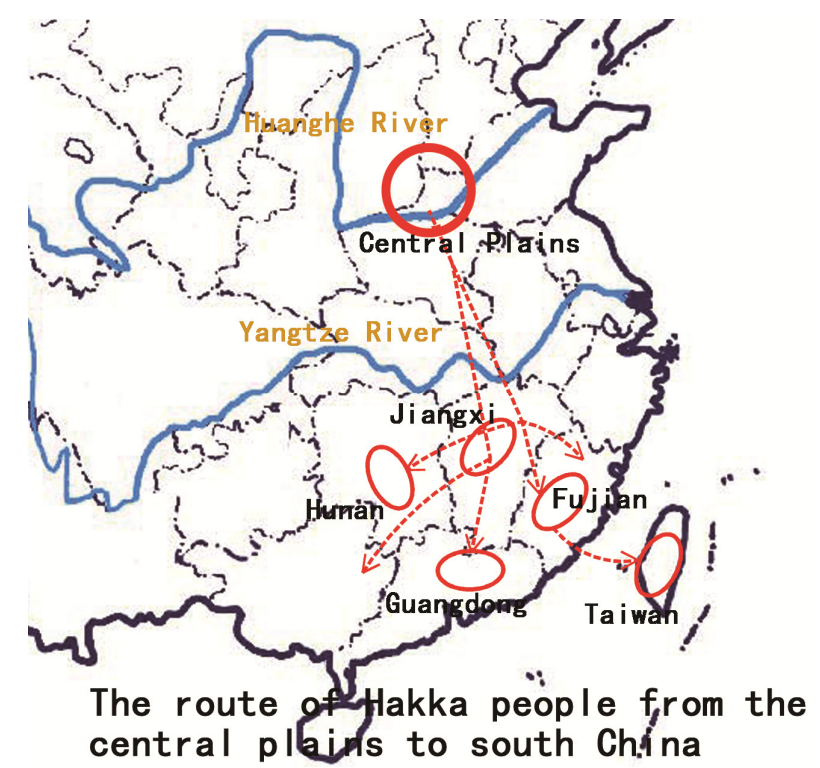

Illustration: Shaosen Wang + Shijie Liao, 2012.11; Southern area: Such as the follows: Jiangxi, Fujian, Guangdong, Hunan, and Taiwan.

Figure 3. The overall harmony of the Hakka culture: Center and inside relation.

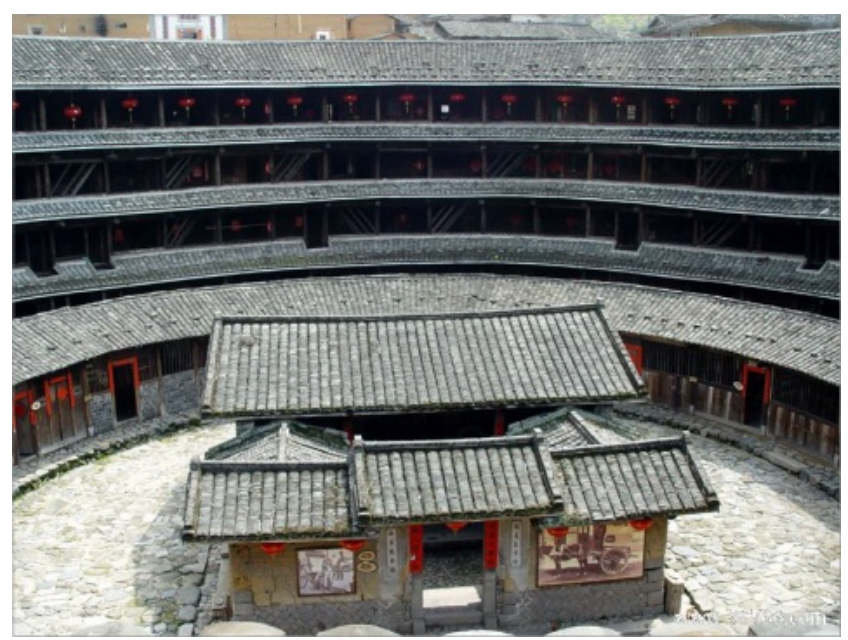

Photo: SamWang 2011.6. 


\subsection{Adaptable to Conditions, Respect of Nature}

In China, the classical philosophy insists on the harmony between the building and the surrounding nature. When selecting the site of settlement, the natural environment is deeply considered and respected, such as choosing a site with water in front and a hill at the back. This is what is called "Feng-Shui" (Chinese traditional concept for the relations between human being and nature), in Chinese history, it has become a pattern language (Figure 4). There is a kind of interdependent relation between the Tulou village and the natural environment. The mountains provide rich sources for living and production. The rivers give the convenience of come-and-go. Tulou forms the ecological connection with the nature over a long period of time (Figure 5). On the contrary, with the expansion cities today, people are the first priority, and natural ecology is ignored to some extent. It is becoming more and more difficult for the city to deal with disaster under extreme weather conditions. We should learn from Tulou to improve the relationship between the nature and urbanity.

Figure 4. Feng-Shui pattern language of Tulou site.

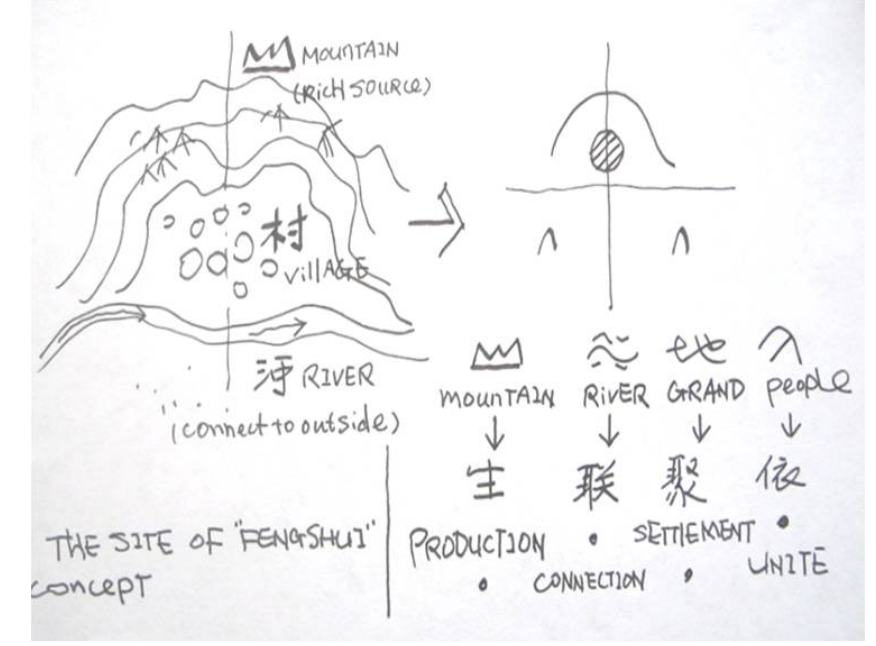

Illustration: Shaosen Wang 2011-6.

Figure 5. Tulou forming an ecological connection with nature.

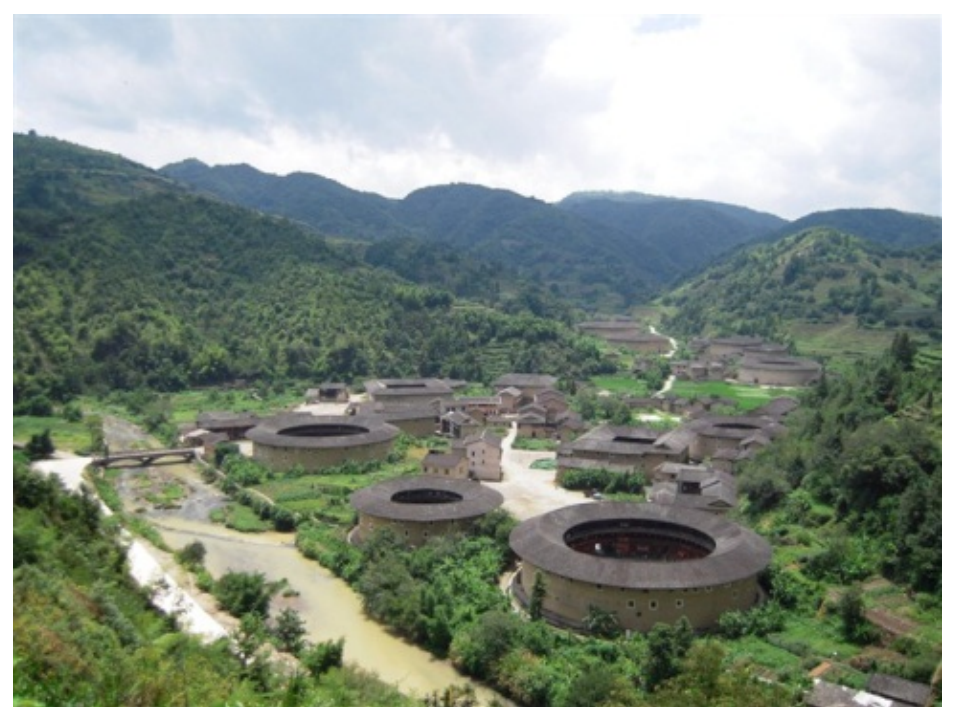

photo: xmuw3m2009-8. 


\subsection{Local Material, Adaptable Technology}

The construction of Tulou is conditioned by the level of technology, economy etc. The Hakka made the most use of local resources. They chose adaptable technology to build houses comfortable to live in (Figure 6). The rammed earth wall building technology is efficient. It saves labor and is easy to get all the necessary local materials (Figure 7). The adaptable technology applied in Tulou provides many significant examples of energy conservation. Tulou has many artistic, technical and ecological values for architecture.

Figure 6. The adaptable technology for the construction of Tulou.

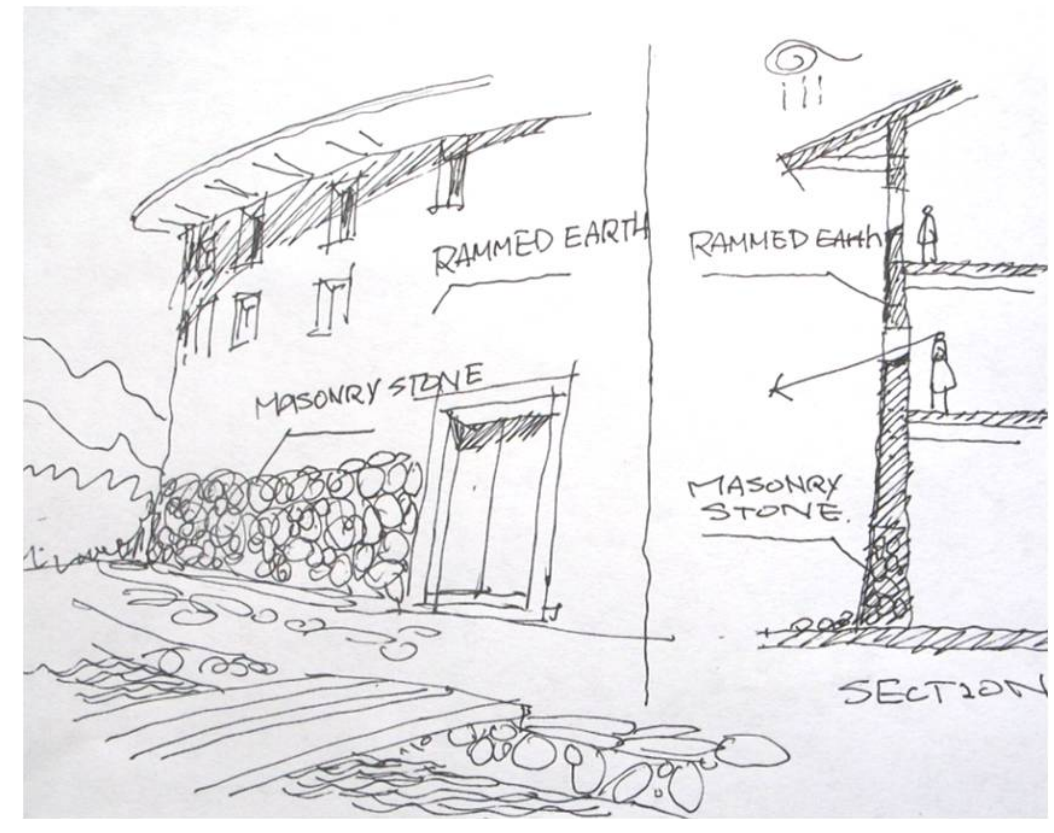

Illustration: Shaosen Wang 2011-6.

Figure 7. Rammed earth and local materials.

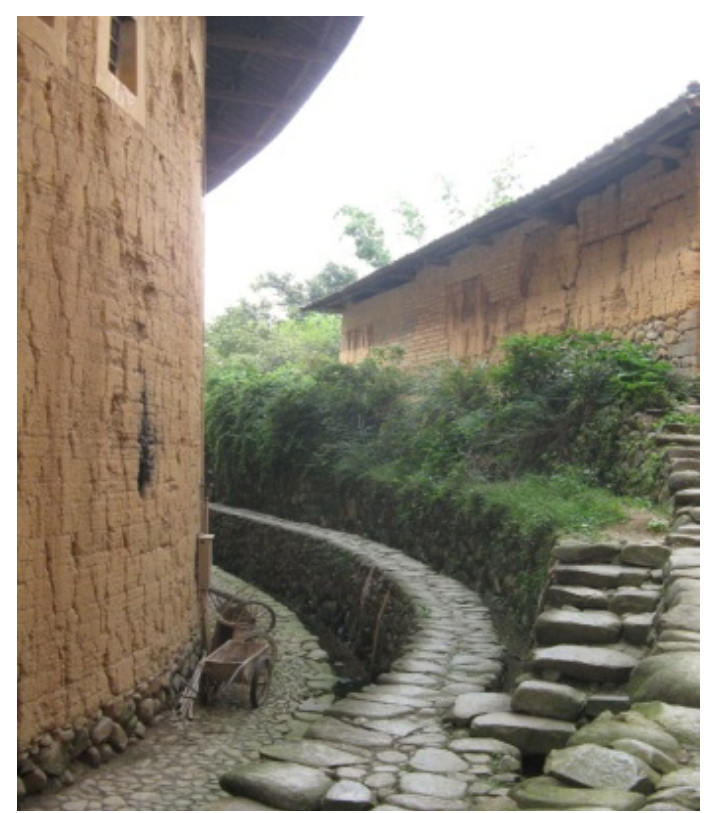

Photo: Samwang 2006-7. 


\section{The Genes of Physical Morphology}

Genes of physical morphology can be absorbed and applied in an effective way for architecture preservation. These include the free styles of overall layout of Tulou villages, and the strict round or square shape planned for an individual Tulou house. Characteristic expression in form, space, construction and material, etc.- - all of these have been inherited into a vital gene pool of Tulou, from which we can learn a lot for the regional architectural design of today (Figure 8).

\subsection{The Genes of Tulou: The Overall System}

Tulou entirely follows the architectural tradition of China: Overall balance and order of building groups. The axis hold in a Tulou cluster is based on physical geography, instead of on social hierarchy. The layout of the building group adjusts the relation between nature and society in a topological method depending on who is living in the Tulou and using the Chinese special pattern language of architecture, such as Feng-Shui, Confucian philosophy, or Taoism and Buddhism (without professional architects). Collective consciousness and public participation promote the adjustment. Paying close attention to the overall environment is vital in the preservation and sustainable development of Tulou.

\subsection{The Genes of Individual Tulou Houses}

The plan prototype of Tulou includes circles, squares, rectangles, or a combination. It follows the precise composing principles, this morphology is very interesting and forms a lot of special space spirits. The fine order of Tulou is worth inheriting in order to improve today's architectural design language. The overall appearance of color of Tulou matches the earth around it, and obtains the organic connection with the earth, yet still bears some vivid colors in the window frames, door heads, spring festival scrolls, etc.

The two-storey bottom of a Tulou is solid, with no windows, for the purpose of defense. Windows are open only from the third to fifth storeys, with varying sizes. Extended eaves are used to prevent rain from dampening the rammed earth walls. The shine shadow of the windows and eaves makes rich layers and gives a stereoscopic feeling; Tulou presents a unique beauty.

The concept that "the form follows the function" is well embodied in the Tulou house, which is full of vitality even today. Poetic architectural space is made by adaptable techniques, such as regional construction methods and use of local materials. The earth-wood-structured Tulou focuses on the ecological factures of material, which mirrors some sustainable design concepts.

The inside and outside spatial patterns in Tulou are differentiated. The layout of Tulou followed the "closed outside, open inside" concept: An enclosure wall with living quarters around the periphery and a common courtyard at the center. The interstitial space between one Tulou house and another is very special, as people can get a feeling of being "in between" when in it, and the space of "in between (gap)" of the Tulous provides a variety of living scenes and is the spirit of the space of Tulou. Nowadays, some new elements intervene in the self-enclosed Tulou that will help to adapt it to a new situation. The mix may bring the genetical modification in its form, space, material and concept. The in-between space does have potential value for the preservation and sustainable development of Tulou. 
Figure 8. Tulou Genbank for the regional architectural design of today.

(a) System: keep and variation

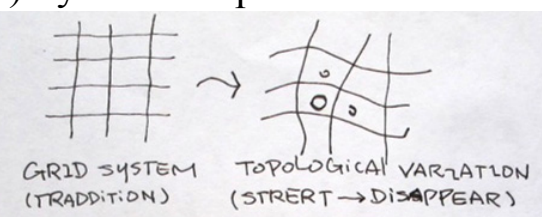

(D)

- DEFENSE Funtion

- Live with same familly

- Design with Nature.

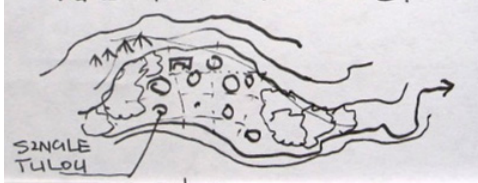

(Illustration: Shaosen Wang 2011-06)

(d) Form: color and material

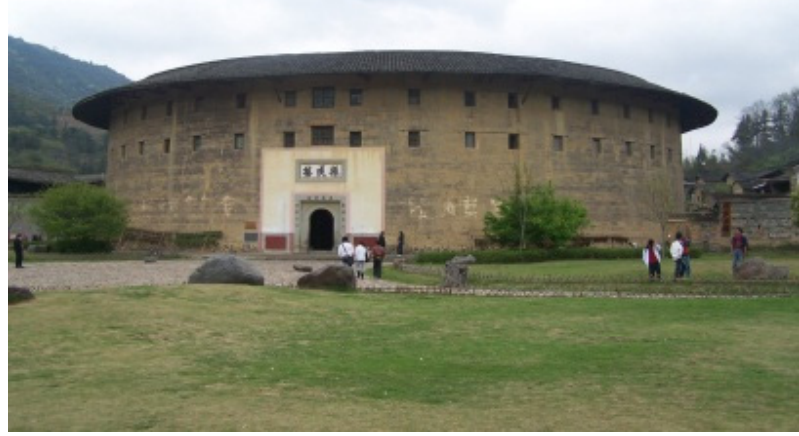

(Photo: nipico 2010-06) (b) Relation: order of building

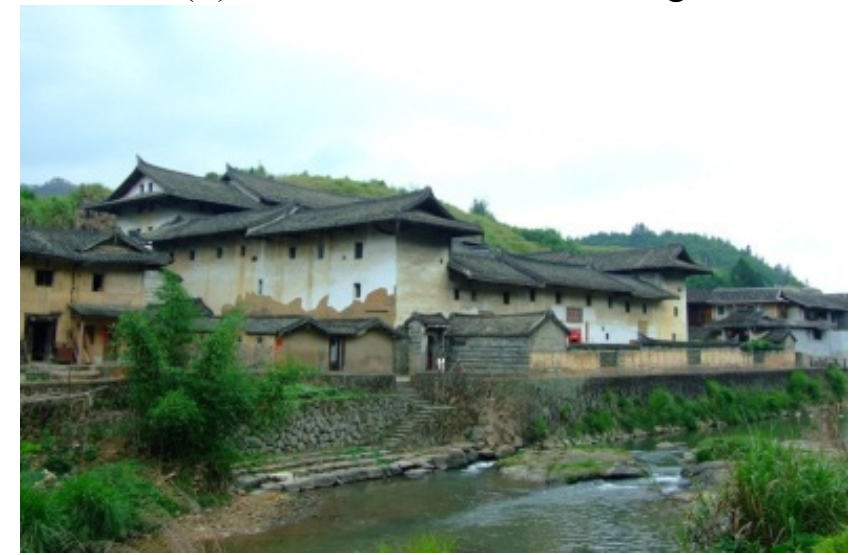

(Shaosen Wang 2010-09)

(e) Space: outside and inside

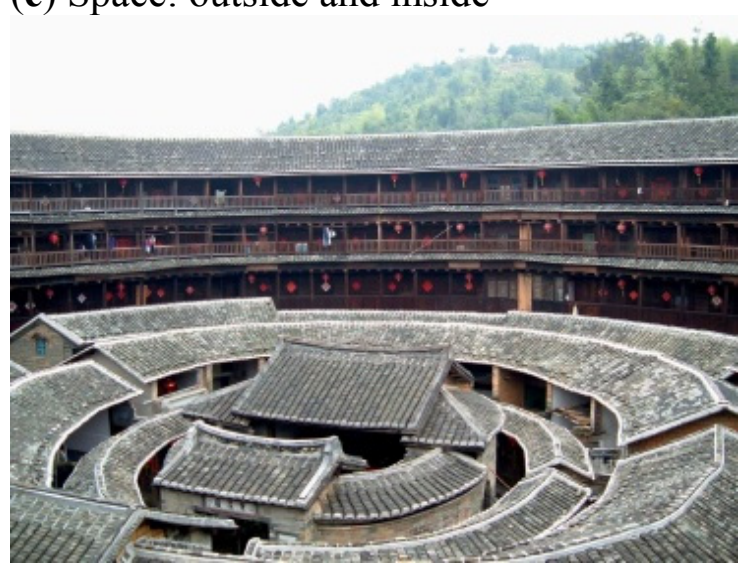

(Photo: xmuw3m 2011-10) (c) Relation: connection to context

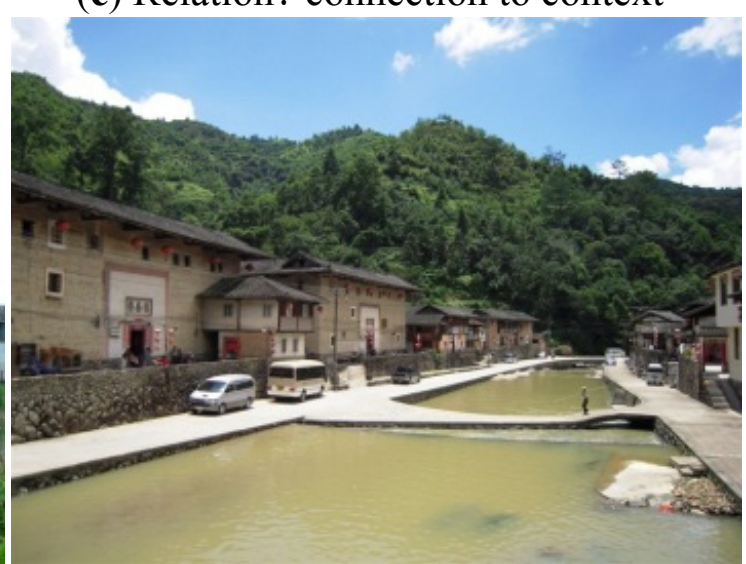

(Photo: nipico 2010-06)

(f) Space: in and between

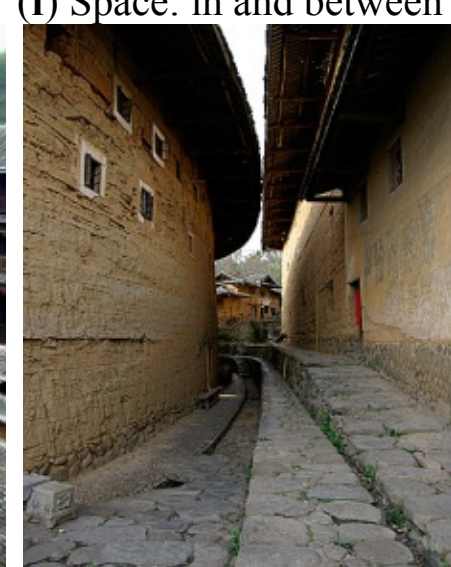

(Photo: Shaosen Wang 2010-09) 


\section{Thinking about Protection and the Sustainable Development of Tulou}

\subsection{Protection and the Sustainable Development of Tulou}

As another type of architecture, Tulou has the following properties: Time and space, technology, artistry, ethnicity and regionalism, history and age. The Tulou gene is an important part of the protection development of Tulou. The socio-cultural gene and physical gene of Tulou should be used in different types of approaches and concern in its protection and development. Tulou protection is focused on the protection of traditional culture and history of the nation, the inheritance of the harmonious spirit, and the concept of natural ecosystems. The key to all the elements above is a holistic and systemic protection, such as treating a Tulou village as a complete system and thus protecting a whole village and its surrounding environment. Tulou sustainable development lies in learning and development of Tulou genes for today's design. We engage our Tulou regionalism design with modernism. The following features are, indeed, feasible: A natural experience, climate conscientiousness, cultural heritage, form abstraction, space creation, materials and tectonics - all these should be combined with modern life and aesthetics to create sustainability development out of the Tulou gene. Abstractly, Tulou protection and sustainable development thinking can be summarized in the following Table 1.

Table 1. Tulou gene protection and development abstract.

\begin{tabular}{cccc}
\hline Type & Keywords & Approaching & Function \\
\hline $\begin{array}{c}\text { 1.Tulou gene } \\
\text { protection }\end{array}$ & entirety & whole village protection & Protecting culture and history \\
nastem & Nature-village-house-site-place & harmony \\
\hline $\begin{array}{c}\text { 2.Tulou gene } \\
\text { sustainable }\end{array}$ & times & Combining modern tech with & modern life adaptation-aim \\
development & culture & traditional skill & \\
& & culture heritage, & the soul of cultural gene-duty \\
& space creation, & the essence of regional gene- \\
& regionalism & natural experience, & essence \\
& & climate conscientiousness, & \\
& & using local materials & \\
\hline
\end{tabular}

Shaosen Wang 2012-11.

\subsection{Tulou Regionalism Design Project-Case Analysis}

This project is a hotel with Tulou style, located in the Tulou region near a river in Ruijin Hakka region. The basic information of the project is listed in Table 2.

Table 2. The basic information of Tolou hotel

\begin{tabular}{cc}
\hline Category & Content \\
\hline Site area & 2.77 ha \\
Total area & $41000 \mathrm{~m}^{2}$ \\
Building & hotel and resort \\
Location & Jiangxi Ruijin (Hakka region) China \\
Designer & Shaosen Wang, Guangming Gao \\
Design time & $2011-7$ \\
\hline
\end{tabular}


The designer excavated the river into the site, designed a water garden between the hotels and resorts, and made the master plan close to nature with some other differently sized gardens. The design obtained an organic connection with nature that is the Tulou gene essence; the hotel was designed with circular morphology to match the crossroads corner, as well as with a connection to the Tulou prototype. The architectural form, color, and space were abstracted from Tulou with professor Shaosen Wang's pan-architecture diagram method, which uses a diagram to study urban architecture and landscape abstractly (Figure 9). This design attempted to analyze Tulou gene application and embody the combination between Tulou regionalism and modernity (Figures 10 and 11).

Figure 9. Abstract methods from the genes of Tulou.
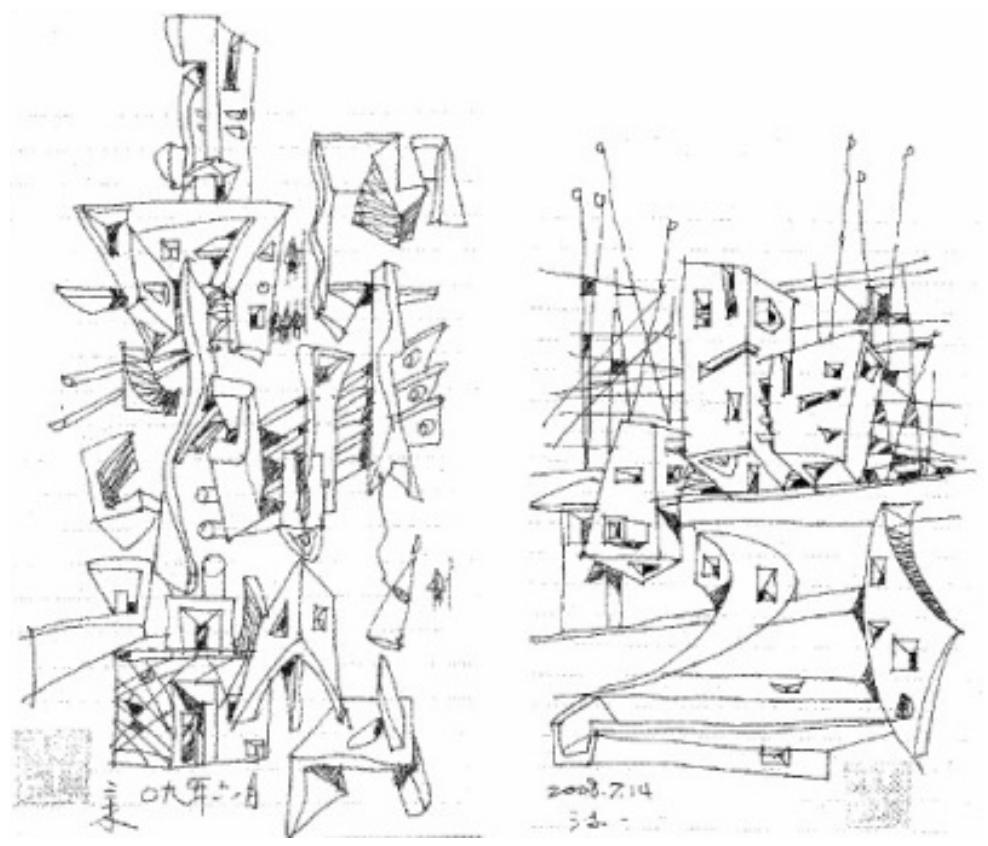

Illustration: Shaosen Wang 2009-06; the left of figure 9 is about "intervention and development with context", the right is about "the composite system of urban with difference elements".

Figure 10. Design with Tulou regionalism (the site plan was designed with a natural hill and river).

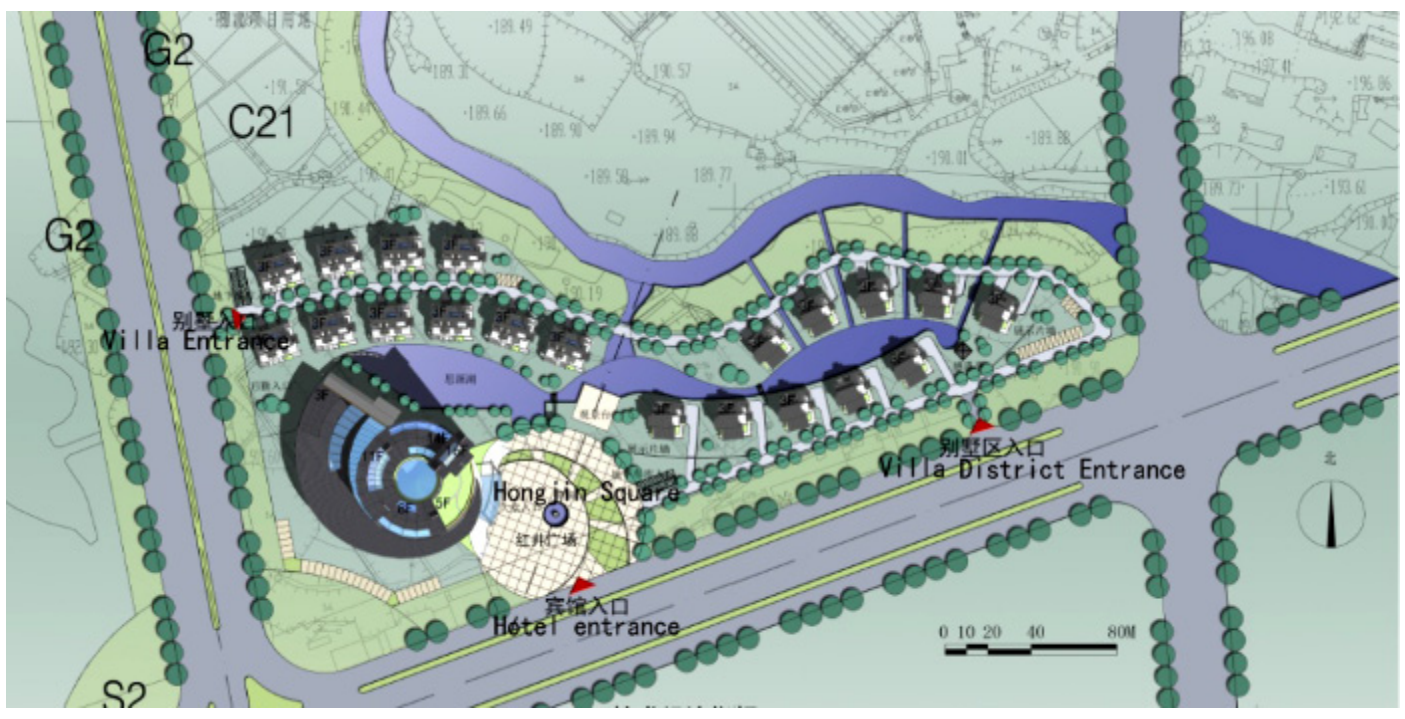


Figure 11. A hotel design with Tulou regionalism.

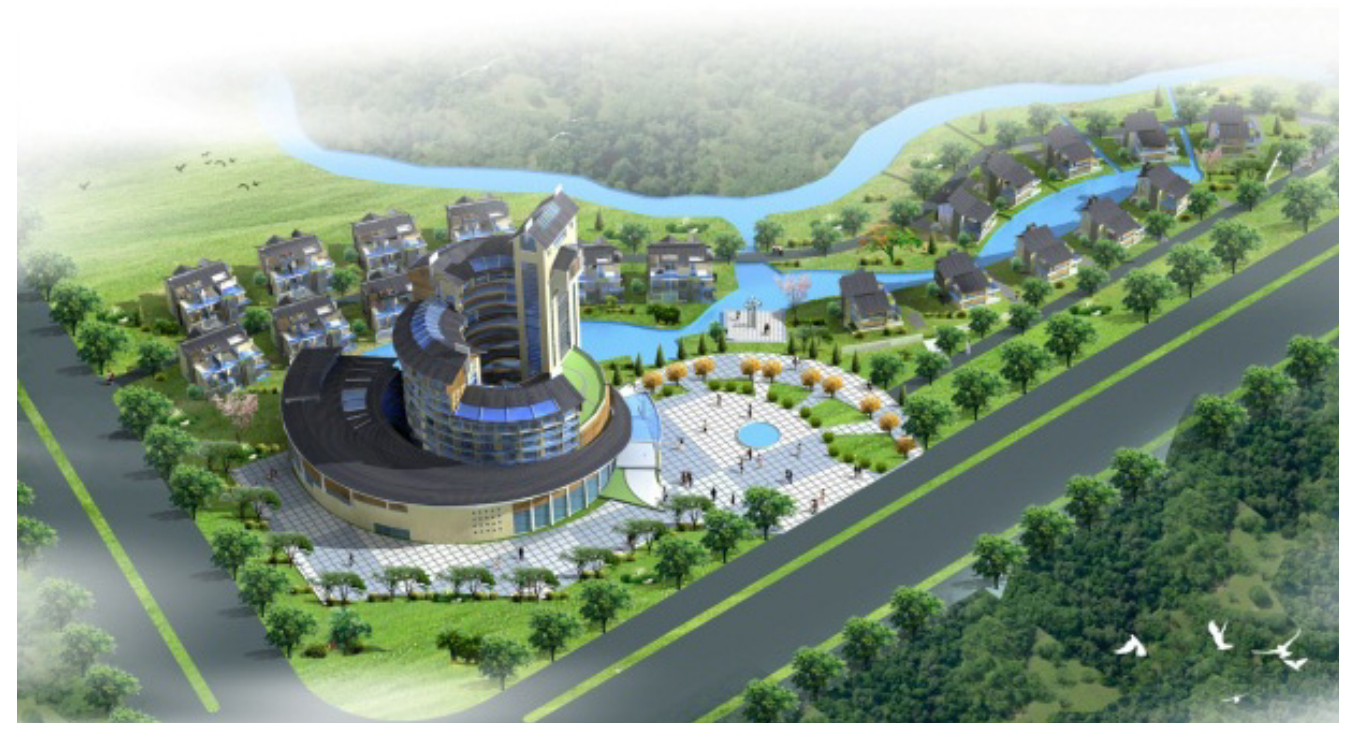

Design: Shaosen Wang +GM Gao 2010-110; The taller hotel was abstracted from Tulou.

\section{Conclusions}

The study on the genes of Tulou is an essential part of preservation and renovation of Tulou. The two gene groups have different applying methods, and different functions in the preservation and development of Tulou. Genes of social culture value the preservation of the harmonious spirit of Tulou. Genes of physical morphology value both the overall system and the genetic modification by new intervention in Tulou building. Through this genetic modification, Tulou will maintain its sustainable development in the new era.

\section{Conflict of Interest}

The author declares no conflict of interest.

\section{References}

1. Shi, Y. Tu Wei Lou; China Travel and Tourism Press: Beijing, China, 2005; pp. 6-8.

2. Shi, Y. Applied Anthropology; Xiamen University Press: Xiamen, China, 1996; pp.18-24.

3. Lowe, K.D. Heaven and Earth-Sustaining Elements in Hakka Tulou. Sustainability 2012, 4, 2795-2802.

4. Ueda, M. A preliminary environmental assessment for the preservation and restoration of Fujian Hakka Tulou Complexes. Sustainability 2012, 4, 2803-2817.

5. Wang, S. Introduction to Architecture; Science Press: Beijing, China, 2000; pp. 12-15. .

6. Wang, Z. Introduction to Architecture Design; Southeast University Press: Nanjing, China, 2010; pp. 20-22.

(C) 2012 by the authors; licensee MDPI, Basel, Switzerland. This article is an open access article distributed under the terms and conditions of the Creative Commons Attribution license (http://creativecommons.org/licenses/by/3.0/). 